\title{
Informed Choice and Informed Consent in Family Planning Services in Independent Practice Midwives
}

\author{
Informed Choice dan Informed Consent dalam Pelayanan Keluarga Berencana (KB) \\ di Bidan Praktek Mandiri (BPM)
}

Reni Tri Lestari'; R.A. Antari Innaka T ${ }^{2}$

email: renitrilestari@yahoo.com

${ }^{1}$ DIII Study Program, Midwifery College of Health Sciences AKBIDYO

${ }^{2}$ Faculty of Law, Gadjah Mada University, Yogyakarta

\begin{abstract}
Midwife is very important to success in continuity of family planning program. This study aims to determine and analyze the Implementation of Informed Consent to Family Planning Service.

The research is an empirical research. The research material consisted of primary and secondary data. Primary data obtained from research subjects, while secondary data obtained from document studies, this study was analyzed by quantitative methods and presented descriptively.

The results showed that the implementation of informed consent in family planning services was good category as much as $37(78,7 \%)$, enough 10 (21,3\%) and impelentasi less none (0\%). The implementation informed consent is mostly good, it is supported by family planning counseling training and Contraceptives Technology Update (CTU).
\end{abstract}

Keywords : Informed Choice, Informed Consent, Family Planning

Abstrak: Bidan memegang peranan dalam kesinambungan keberhasilan program KB. Bidan sebagai tenaga professional, memikul tanggungjawab atas pelayanan yang diberikan dan berupaya secara optimal dengan mengutamakan keselamatan klien. Bidan harus dapat mempertahankan tanggungjawabnya bila terjadi gugatan terhadap tindakan yang dilakukannya. Pasien yang telah menentukan pilihan alat kontrasepsi yang dipilih, selanjutnya bidan berperan dalam proses pembuatan informed consent. Penelitian ini bertujuan untuk mengetahui dan menganalisa bagaimanakah informed choice dan informed consent dalam pelayanan Keluarga Berencana (KB) Di Bidan Praktik Mandiri (BPM).

Penelitian ini merupakan penelitian yuridis empiris. Bahan penelitian terdiri dari data primer dan data sekunder. Data primer diperoleh dari subyek penelitian, sedangkan data sekunder diperoleh dari studi dokumen, jumlah sampel dalam penelitian sebanyak 47 BPM. Penelitian dianalisis dengan metode kuantitatif dan dipaparkan secara deskriptif.

Hasil penelitian menunjukkan bahwa informed choice dan informed consent dalam pelayanan KB di BPM kategori baik sebanyak 37 BPM (78,7\%), kategori cukup sebanyak 10 BPM (21,3\%) dan kategori kurang tidak ada (0\%). Mayoritas informed choice dan informed consent dalam pelayanan KB di BPM kategori baik ini didukung oleh kegiatan bidan dalam meningkatkan pengetahuannya dengan mengikuti pelatihan konseling KB dan pelatihan Contraseptives Technology Update (CTU).

Kata kunci: Informed Choice, Informed Consent, Keluarga Berencana. 


\section{PENDAHULUAN}

Kesehatan adalah keadaan sehat baik secara fisik, mental, spiritual maupun sosial yang memungkinkan setiap orang hidup produktif secara sosial dan ekonomis'. Sumber utama pernyataan tentang kesehatan dalam arti kesejahteraan berakar dari kesepakatan internasional yaitu tentang pelayanan kesehatan yang berunsur hak asasi manusia dan kesejahteraan, hak asasi manusia menjadi dasar utama pengadaan informed consent, dalam menyelenggarakan pelayanan kesehatan.

Hakekat pengertian informed consent tidak boleh dihubungkan atau dijabarkan dari upaya atau pemikiran untuk menghindarkan atau membebaskan diri dari tanggungjawab risiko, dan atau semata-mata untuk dapat dilakukannya suatu tindakan secara sah. Pandangan yang mendasari informed consent dikemukakan oleh Veatch yaitu yang pertama teori manfaat untuk pasien, pandangan mengenai hal yang baik dan bermanfaat bagi pasien tertentu tidak sama antara pasien satu dengan pasien lainnya, bergantung dengan situasi dan kondisi pribadi serta nilai yang dianut pasien. Pemberian informasi kepada pasien harus dilakukan sehingga pasien dapat berperan serta dalam pengambilan keputusan dan secara aktif pasien menguasainya agar semaksimal mungkin dapat memperoleh manfaatnya. Teori yang kedua yaitu teori manfaat bagi pergaulan hidup, pandangan teori ini terhadap pengertian manfaat tidak dibatasi oleh pertimbangan ekonomis, nilai estetika, kebudayaan, keagamaan dan psikologis. Teori yang ketiga, teori menentukan nasib sendiri. Hak individu untuk menentukan nasib sendiri memberikan dasar yang otonom bagi syarat informed consent ${ }^{2}$.

Misi paradigma baru program KB sangat menekankan upaya menghormati hak-hak reproduksi, sebagai upaya integral dalam meningkatkan kualitas keluarga yang berdasar pada rencana strategi nasional Making Pregnancy Safer (MPS) bahwa setiap kehamilan harus merupakan kehamilan yang diinginkan³. Bidan sangat memegang peranan dalam keberhasilan program KB. Bidan sebagai tenaga professional, memikul tanggungjawab atas pelayanan yang diberikan dan berupaya secara optimal dengan mengutamakan keselamatan klien. Bidan harus dapat mempertahankan tanggungjawabnya bila terjadi gugatan terhadap tindakan yang dilakukannya4.

Informed choice dan informed consent penting dalam pelayanan $\mathrm{KB}$, informed choice berarti membuat pilihan setelah mendapat penjelasan tentang alternatif asuhan yang akan dialaminya. Pilihan (choice) lebih penting dari sudut pandang wanita (pasien) yang memberikan gambaran pemahaman masalah yang berhubungan dengan aspek etika dalam otonomi pribadi. Hal ini sejalan dengan Kode Etik Internasional Bidan bahwa bidan harus menghormati hak-hak perempuan setelah

\footnotetext{
Pasal 1 ayat 1 Undang-Undang Nomor 36 Tahun 2009 tentang Kesehatan

2 Veronica Komalawati, 2002, Peranan Informed Consent dalam Transaksi Terapeutik (Persetujuan Dalam Hubungan Dokter dan Pasien) Suatu Tinjauan Yuridis, PT Citra Aditya Bakti, Bandung.

3 Marmi, 2014, Etika Profesi Bidan, Pustaka Pelajar, Yogyakarta.

4 Masrudi Muchtar, 2015, Bidan dan Dinamika Hukum Kesehatan Reproduksi di Indonesia, Aswaja Pressindo, Yogyakarta.
} 
mendapatkan penjelasan dan mendorong perempuan untuk menerima tanggungjawab terhadap hasil dari pilihannya ${ }^{5}$. Banyak perempuan mengalami kesulitan dalam menentukan pilihan jenis kontrasepsi. Hal ini tidak hanya karena terbatasnya metode kontrasepsi yang tersedia, tetapi juga ketidaktahuan tentang persyaratan, keamanan metode kontrasepsi, dan faktor lain yang harus dipertimbangkan termasuk status kesehatan, efek samping, konsekuensi kegagalan, besar keluarga yang direncanakan, persetujuan pasangan, bahkan norma budaya lingkungan dan orang tua ${ }^{6}$.

Informed consent adalah persetujuan yang diberikan oleh pasien atau walinya kepada bidan untuk melakukan tindakan sesuai kebutuhan. Informed consent adalah suatu proses bukan suatu formulir atau selembar kertas dan merupakan suatu dialog antara bidan dan pasien atau walinya yang didasari akal dan pikiran yang sehat dengan suatu birokratisasi yakni penandatanganan suatu formulir yang merupakan jaminan atau bukti bahwa persetujuan dari pihak pasien atau walinya telah terjadi. Informed choice dan informed consent merupakan perlindungan bagi bidan dan memberikan dampak rasa aman dan nyaman bagi pasien?. Persetujuan atau consent penting dari sudut pandang bidan, karena berkaitan dengan aspek hukum yang memberikan otoritas untuk semua prosedur yang akan dilakukan bidan. Pengamatan yang dilakukan peneliti, peran bidan dalam pemberian Konseling Informasi dan Edukasi (KIE) sebagai bentuk pelaksanaan informed choice belum dilakukan secara maksimal, sedangkan pasien memiliki hak untuk mendapatkan KIE tentang alat kontrasepsi. Pemilihan alat kontrasepsi yang rasional perlu dipertimbangkan, antara lain pemilihan yang sesuai dengan kebutuhan klien, efisien, kemudahan penggunaan, keamanan, kemungkinan pemulihan dan kemudahan penyediaan serta terdapat faktor lain yang mempengaruhi dalam pemilihan kontrasepsi ${ }^{8}$.

Hubungan tenaga kesehatan dengan pasien dalam hukum kesehatan terjalin dalam ikatan transaksi terapeutik. Setiap tindakan medis harus didasari oleh kaidah dasar bioetik (KDB), etika kebidanan, hukum yang berlaku serta tidak menyimpang dari norma-norma yang berlaku di masyarakat. Tindakan medis tidak menjanjikan hasil, dipilih option yang risikonya paling kecil, hukum dan undang-undang adalah mutlak, tidak boleh dilanggar. Etika, moral dan agama adalah permasalahan yang nantinya dikembalikan kepada individu masing-masing. Prinsip utama tindakan untuk memberikan pelayanan KB dalam KDB memiliki kriteria beneficence dan autonomy ${ }^{9}$

\footnotetext{
5 ICM, 1993, Kode Etik Internasional Bidan, sebagaimana dimuat dalam laman https://lenteraimpian.wordpress.com/2010/02/10/informed-choice-dan-informed-concent/ terakhir diakses pada 20 Mei 2016.

6 Saifuddin, A.B. 2011, Buku panduan Praktis Pelayanan Kontrasepsi Edisi Ketiga, PT Bina Pustaka Sarwono Prawirohardjo, Jakarta.

7 Marmi, 2014, Etika profesi Bidan, Pustaka Pelajar, Yogyakarta.

8 Saifuddin, A.B, dkk, 2012, Buku Panduan Pelayanan Kontrasepsi, PT Bina Pustaka Sarwono Prawirohardjo, Jakarta.

9 Konsil kedokteran Indonesia Penyelenggaraan Praktik Kedokteran Yang Baik di Indonesia 2006.
} 
Data menyebutkan di kabupaten Bantul pelayanan KB dengan pasien baru diberikan informed consent, namun pelaksanaannya belum maksimal. Pasien baru metode kontrasepsi jangka panjang (MKJP) dan metode suntik sebanyak 892 yang diberikan informed consent sebanyak $729^{10}$. Pelayanan KB dapat diberikan oleh Bidan, jumlah bidan praktek mandiri di Bantul sejumlah 88 BPM, yang terbagi menjadi 3 ranting yaitu 33 ranting barat, 29 ranting tengah, 26 ranting timur. Dari pengamatan penulis, pemberian KIE kepada akseptor KB belum dilakukan secara maksimal, pemberian konseling tentang kontrasepsi belum secara menyeluruh. Berdasarkan uraian diatas, penulis merasa tertarik untuk meneliti kaitannya dengan pelaksanaan informed choice dan informed consent.

\section{PERUMUSAN MASALAH}

Berdasarkan latar belakang masalah penelitian, maka rumusan masalah dalam penelitian ini adalah "Bagaimanakah informed Choice dan Informed Consent Dalam Pelayanan Keluarga Berencana (KB) Di Bidan Praktik Mandiri (BPM) Wilayah Bantul ?

\section{METODE PENELITIAN}

Penelitian ini merupakan penelitian dekriptif dengan pendekatan yuridis empiris yaitu menyajikan deskripsi lengkap dari suatu fenomena yang terjadi menggunakan normanorma hukum yang bersifat menjelaskan dengan cara meneliti dan membahas peraturanperaturan hukum yang berlaku saat ini. Lokasi penelitian di BPM wilayah Bantul dengan subjek penelitian yaitu bidan yang memiliki BPM.

Variabel penelitian ini adalah variabel tunggal yaitu Informed choice dan Informed consent pelayanan KB pada bidan yang memiliki BPM. Sumber data primer diperoleh dengan cara memberikan kuesioner kepada responden. Peneliti menjelaskan cara menjawab kuesioner kepada responden. Responden menjawab pertanyaan dengan cara menceklist $(V)$ jawaban yang sesuai dan menjawab pertanyaan isian pada lembar jawaban yang telah disediakan peneliti. Responden diberi waktu 2 hari untuk mengisi kuesioner, selanjutnya peneliti mengambil kuesioner yang telah terisi setelah 2 hari. Guna mendukung analisis data kuantitatif, peneliti menambahkan kuesioner terbuka. Responden dapat menceritakan dan menggali pelaksanaan informed choice dan informed consent dalam pelayanan KB sesuai dengan pertanyaan dari peneliti. Peneliti menafsirkan dan menjabarkan data berdasarkan teori-teori hukum atau kaedah hukum dan doktrin hukum yang relevan guna menjawab permasalahan yang dirumuskan.

Informed choice dan informed consent dalam pelayanan KB di BPM wilayah Bantul diukur berdasarkan jawaban responden terhadap kuesioner tertutup yang diberikan sebanyak 25 pertanyaan. Penilaian informed choice dan informed consent dalam pelayanan KB di BPM oleh penulis digolongkan menjadi 3 kategori yaitu baik jika nilai $76 \%-100 \%$, cukup jika nilai $56 \%-75 \%$, dan kurang jika nilai kurang dari $56 \%$.

10 BKKBN Bantul. 2015, Data Hasil Kegiatan Program KB Nasional Kabupaten Bantul. 
PEMBAHASAN

Tabel 1

Distribusi Frekuensi Responden Berdasarkan Keikutsertaan dalam Pelatihan Konseling Keluarga Berencana (KB)

\begin{tabular}{ccc}
\hline Pelatihan Konseling KB & Frekuensi & Persentase \\
\hline Belum & 7 & $14,9 \%$ \\
Sudah & 40 & $85,1 \%$ \\
\hline Jumlah & 47 & $100 \%$ \\
\hline
\end{tabular}

Sumber: Data Primer 2017

Berdasarkan tabel 1 menunjukkan karakteristik bidan yang telah melaksanakan pelatihan konseling Keluarga Berencana (KB) sebagian besar responden sudah mengikuti pelatihan konseling KB sebanyak 40 bidan (85,1\%) dan sebagian kecil belum melaksanakan pelatihan konseling KB sebanyak 7 bidan (14,9\%).

Salah satu keterampilan dasar bidan dalam pelayanan KB yang dapat membantu keberhasilan pelayanan KB yaitu keterampilan memberikan konseling. Hal ini sesuai dengan Keputusan Menteri Kesehatan Nomor 369 Tahun 2007 tentang Standar Profesi Bidan. Kompetensi bidan yang kedua yaitu pengetahuan dasar mengenai berbagai metode alamiah untuk menjarangkan kehamilan, jenis, indikasi, cara pemberian, cara pencabutan dan efek samping berbagai kontrasepsi yang digunakan antara lain pil, suntik, AKDR, alat kontrasepsi bawah kulit (AKBK), kondom, tablet vagina dan tisu vagina. Bidan juga harus mempunyai pengetahuan dasar mengenai metode konseling bagi wanita dalam memilih suatu kontrasepsi. Selain itu, bidan harus memiliki ketrampilan dasar untuk melaksanakan pendidikan kesehatan dan keterampilan konseling dasar dengan tepat. Keterampilan konseling ini memiliki peran penting dalam mempengaruhi pasangan usia subur (PUS) untuk berKB. Bidan sebagai penyedia layanan KB diharapkan terampil dalam memberikan konseling.

Berdasarkan hasil penelitian, menunjukkan bahwa dari karakteristik responden jumlah bidan yang mengikuti pelatihan konseling $\mathrm{KB}, 40$ responden $(85,1 \%)$ bidan yang memberikan pelayanan KB di BPM telah melakukan pelatihan konseling KB. Hal ini menunjukkan bahwa dalam memberikan pelayanan KB, bidan di BPM Bantul telah memiliki kompetensi yang mendukung dalam melaksanakan pelayanan KB. Konseling KB merupakan aspek yang sangat penting dalam pelayanan KB dan kesehatan reproduksi. Konseling yang baik dapat membatu pasien merasa puas, membantu klien dalam menggunakan kontrasepsimya lebih lama dan meningkatkan keberhasilan KB serta mempengaruhi interaksi antara tenaga kesehatan (bidan) dengan klien yang akan meningkatkan hubungan kepercayaan yang sudah ada. Teknik konseling yang baik dan memadai harus diterapkan dan dibicarakan secara interaktif sepanjang kunjungan klien dengan cara yang sesuai dengan budaya yang ada. Informasi yang lengkap dan cukup akan memberikan keleluasaan klien dalam memutuskan untuk memilih kontrasepsi (Informed Choice) yang akan digunakan klien. Hasil penelitian dari kuesioner terbuka menyatakan bahwa terdapat pengaruh pelatihan konseling KB dengan implementasi informed choice dan informed consent dalam pelayanan 
KB. Konseling KB dapat mendorong klien untuk mengajukan pertanyaan, menjadi pendengar aktif, menjamin klien penuh informasi dan membantu klien membuat pilihan sendiri. ${ }^{11}$ Jawaban responden menunjukkan bahwa jawaban telah mengarah pada tujuan konseling, diantaranya terdapat komunikasi 2 arah antara bidan dan pasien, memahami kebutuhan pasien, melindungi hak-hak reproduksi pasien. Selain itu, menurut responden pengaruh dari pelatihan konseling KB yaitu meningkatkan pengetahuan dan merefresh kembali pengetahuan seputar KB, meningkatkan pengetahuan tentang teknik konseling serta melaksanakan informed choice dan informed consent dalam pelayanan KB yang diberikan pada saat sebelum dan sesudah tindakan medik.

Tabel 2

Distribusi Frekuensi Tahun Keikutsertaan Responden dalam Pelatihan Konseling Keluarga Berencana

\begin{tabular}{ccc}
\hline Tahun & Frekuensi & Persentase \\
\hline 2000 & 1 & $2,5 \%$ \\
2007 & 2 & $5 \%$ \\
2008 & 8 & $20 \%$ \\
2009 & 2 & $5 \%$ \\
2010 & 4 & $10 \%$ \\
2012 & 4 & $10 \%$ \\
2013 & 6 & $15 \%$ \\
2014 & 7 & $17,5 \%$ \\
2015 & 4 & $10 \%$ \\
2016 & 2 & $5 \%$ \\
\hline Jumlah & 40 & $100 \%$ \\
\hline
\end{tabular}

Sumber : Data Primer 2017

Berdasarkan tabel 2, keikutsertaan responden dalam pelatihan konseling KB paling banyak pada tahun 2008 yaitu sebanyak 8 bidan (20\%) dan paling sedikit 1 bidan $(2,5)$.

Waktu keikutsertaan responden dalam pelatihan konseling KB dari 40 responden yang pernah mengikuti pelatihan 27 responden (67,50\%) mengikuti pelatihan diatas tahun 2010. Keterampilan konseling KB bagi bidan sangat diperlukan, karena kemampuan melakukan konseling yang baik dapat membantu klien untuk mengambil keputusan menggunakan salah satu metode kontrasepsi yang tepat. Konseling bagi calon akseptor KB baru maupun akseptor lama merupakan bagian dari implementasi informed choice. Informed choice berarti membuat pilihan setelah mendapat penjelasan tentang alternatif asuhan yang akan dialaminya ${ }^{12}$. Pilihan (choice) lebih penting dari sudut pandang wanita (pasien) yang memberikan gambaran pemahaman masalah yang berhubungan dengan aspek etika dalam otonomi pribadi. Hal ini sejalan dengan Kode Etik Internasional Bidan bahwa bidan harus

\footnotetext{
${ }^{11}$ KIE dalam http://www.lusa.web.id/kie-dalam-pelayanan-kb diakses pada 18 Mei 2017

12 Marmi, 2014, Etika Profesi Bidan, Pustaka Pelajar, Yogyakarta.
} 
SOEPRA Jurnal Hukum Kesehatan

TERAKREDITASI RISTEKDIKTI Peringkat 4

ISSN:2548-818X (media online) Vol. 7 (1) Juni 2021

menghormati hak-hak perempuan setelah mendapatkan penjelasan dan mendorong perempuan untuk menerima tanggungjawab terhadap hasil dari pilihannya ${ }^{13}$.

Tabel 3

Distribusi Frekuensi Keikutsertaan Responden dalam Pelatihan Contraceptive Technology Update (CTU)

\begin{tabular}{ccc}
\hline Pelatihan CTU & Frekuensi & Persentase \\
\hline Belum & 4 & $8,5 \%$ \\
Sudah & 43 & $91,5 \%$ \\
\hline Jumlah & 47 & $100 \%$ \\
\hline
\end{tabular}

Sumber: Data Primer 2017

Berdasarkan hasil penelitian, sebagian besar responden telah melaksanakan pelatihan CTU sebanyak 43 bidan (91,5\%) dan sebagian kecil responden belum melaksanakan pelatihan sebanyak 4 bidan $(8,5 \%)$.

Tidak hanya keterampilan dalam memberikan konseling KB, pengetahuan dan keterampilan bidan harus sesuai dengan perkembangan teknologi terkini. Bidan yang menyediakan pelayanan KB di BPM diharapkan mengupdate ilmu dengan mengikuti pelatihan-pelatihan yang mendukung kompetensi. Berdasarkan hasil penelitian, 43 responden (91,5\%) telah melakukan pelatihan Contraceptive Technology Update (CTU). Hal ini menunjukkan bahwa bidan yang memberikan pelayanan KB di Wilayah Bantul memiliki kompetensi terkini sesuai dengan perkembangan dan inovasi ilmu dalam kebidanan.

Tabel 4

Distribusi Frekuensi Waktu Keikutsertaan Responden dalam Pelatihan Contraceptive Technology Update (CTU)

\begin{tabular}{ccc}
\hline Tahun & Frekuensi & Persentase \\
\hline 2006 & 2 & $4,65 \%$ \\
2008 & 4 & $9,30 \%$ \\
2010 & 5 & $11,64 \%$ \\
2012 & 10 & $23,25 \%$ \\
2013 & 6 & $13,95 \%$ \\
2014 & 6 & $13,95 \%$ \\
2015 & 5 & $11,63 \%$ \\
2016 & 5 & $11,63 \%$ \\
\hline Jumlah & 43 & $100 \%$ \\
\hline
\end{tabular}

Sumber : Data Primer 2017

13 ICM, 1993, Kode Etik Internasional Bidan, sebagaimana dimuat dalam laman https://lenteraimpian.wordpress.com/2010/02/10/informed-choice-dan-informed-concent/ terakhir diakses pada 20 Mei 2016. 
Berdasarkan tabel 4, keikutsertaan responden dalam pelatihan CTU paling banyak pada tahun 2012 yaitu sebanyak 10 bidan (23,25\%) dan paling sedikit pada tahun 2006 (4,65\%).

Teknologi Kontrasepsi Terkini (TKT) atau Contraceptive Technology Update (CTU) merupakan suatu upaya untuk pemutakhiran informasi dan teknologi kontrasepsi. TKT memberikan informasi terkini (evidence-based) dan praktik terbaik (best practices) bagi petugas (provider) bagi perbaikan kualitas dan keamanan pelayanan. Petugas pemberi pelayanan KB akan kompeten terhadap teknologi kontrasepsi sehingga dapat meningkatkan akses dan kepuasan klien akibat hilangnya barier medik dan tingginya mutu pelayanan. Bagaimanapun juga, pemberi pelayanan KB tentunya memerlukan penyegaran pengetahuan dan keterampilan yang disesuaikan dengan kemajuan teknologi kontrasepsi maupun perkembangan ilmu terbaru untuk meningkatkan akses dan mutu pelayanan KB bagi masyarakat. Menurut Peraturan Menteri Kesehatan Republik Indonesia Nomor 1464 Tahun 2010 tentang Izin dan Penyelenggaraan Praktek Bidan Pasal 18 ayat 1 huruf d yaitu dalam melaksanakan praktik bidan berkewajiban untuk meminta persetujuan tindakan kebidanan yang akan dilakukan, bidan dalam menjalankan praktek senantiasa meningkatkan mutu pelayanan profesinya, dengan mengikuti perkembangan ilmu pengetahuan dan teknologi melalui pendidikan dan pelatihan sesuai dengan bidang dan tugasnya ${ }^{14}$. Sebanyak 40 bidan $(85,1 \%)$ dan 43 bidan (91,5\%) memberikan pelayanan KB di BPM Wilayah Bantul telah mengikuti pelatihan konseling KB dan CTU untuk meningkatkan mutu pelayanan KB.

Tabel 5

Distribusi Frekuensi Masa Berlaku STR Responden Informed Choice dan Informed Consent dalam Pelayanan KB

\begin{tabular}{ccc}
\hline Masa Berlaku STR & Frekuensi & Persentasi \\
\hline 2017 & 21 & $44,67 \%$ \\
2018 & 1 & $2,16 \%$ \\
2019 & 7 & $14,88 \%$ \\
2020 & 18 & $38,29 \%$ \\
\hline Jumlah & 47 & $100 \%$ \\
\hline
\end{tabular}

Sumber: Data Primer 2017

Berdasarkan tabel 5, Masa Berlaku STR Responden Informed Choice dan Informed Consent dalam Pelayanan KB paling banyak habis pada tahun 2017 yaitu sebanyak 21 bidan (44,67\%) dan paling sedikit habis pada tahun 2018 yaitu sebanyak 1 bidan (2,16\%).

Bidan praktik mandiri merupakan praktik bidan swasta perorangan, dimana seorang bidan dapat menjalankan praktik mandiri dengan persyaratan minimal Diploma III (DIII) Kebidanan ${ }^{15}$ dan memiliki Surat Izin Praktik Bidan (SIPB) ${ }^{16}$. SIPB dikeluarkan oleh Kepala Dinas Kesehatan Kabupaten/Kota yang seterusnya akan disampaikan laporannya kepada

\footnotetext{
14 Pasal 18 ayat (2) Peraturan Menteri Kesehatan Nomor 1464 tahun 2010 tentang Izin dan Penyelenggaraan Praktik Bidan.

15 Pasal 2 ayat (1) Peraturan Menteri Kesehatan Nomor 1464 tahun 2010 tentang Izin dan Penyelenggaraan Praktik Bidan.

16 Pasal 3 ayat (2) Peraturan Menteri Kesehatan Nomor 1464 tahun 2010 tentang Izin dan Penyelenggaraan Praktik Bidan
} 
SOEPRA Jurnal Hukum Kesehatan

TERAKREDITASI RISTEKDIKTI Peringkat 4

ISSN:2548-818X (media online) Vol. 7 (1) Juni 2021

Kepala Dinas Kesehatan Provinsi setempat dengan tembusan kepada organisasi profesi setempat.

Dalam penelitian ini, peneliti tidak mendapatkan data tentang SIPB responden, namun peneliti mendapatkan data tentang STR (Surat Tanda Registrasi) responden. STR merupakan bukti tertulis yang diberikan oleh pemerintah kepada tenaga kesehatan yang diregistrasi setelah memiliki sertifikat kompetensi ${ }^{17}$. Registrasi merupakan pencatatan resmi terhadap tenaga kesehatan yang telah memiliki sertifikat kompetensi dan telah mempunyai kualifikasi tertentu lainnya serta diakui secara hukum untuk menjalankan praktik dan/atau pekerjaan profesinya ${ }^{18}$. Tujuan registrasi yaitu meningkatkan kemampuan tenaga profesi dalam mengadopsi kemajuan ilmu pengetahuan dan tehnologi yang berkembang pesat, meningkatkan mekanisme yang obyektif dan komprehensif dalam penyelesaian kasus malpraktik, menjaga mutu pelayanan kebidanan, mendata jumlah dan kategori melakukan praktik. Bidan yang sudah teregistrasi, maka akan mendapatkan haknya untuk izin praktik (lisensi) setelah memenuhi beberapa persyaratan administrasi untuk lisensi. STR berlaku selama 5 (lima) tahun dan dapat diregistrasi ulang setiap 5 (lima) tahun sekali dengan tetap memenuhi persyaratan pengajuan STR ${ }^{19}$. Masa berlaku STR responden sampai pengambilan data penelitian sebanyak 21 bidan (44,67\%) masa berlakunya habis pada tahun 2017, dari 21 responden tersebut 10 responden STR habis sampai bulan Maret dan 11 responden STR berlaku April sampai Desember 2017. Dari hasil penelusuran peneliti di Sekretariat IBI Bantul, STR responden yang habis masa berlaku pada tahun 2017 sudah mengajukan perpanjangan STR dan statusnya sedang dalam proses perpanjangan STR.

Bidan merupakan tenaga kesehatan yang merupakan ujung tombak penyedia layanan KB. Hal ini sesuai dengan Kepmenkes Nomor $1464 /$ Menkes/PER/X/2010 20 yang menyatakan bahwa dalam penyelenggaraan praktik bidan berwenang untuk memberikan pelayanan yang meliputi pelayanan kesehatan ibu, pelayanan kesehatan anak, pelayanan KB, dan pelayanan kesehatan reproduksi perempuan. Dalam menjalankan kewenangannya, khususnya dalam pelayanan KB maka bidan dituntut untuk memiliki ilmu pengetahuan dan keterampilan yang kompeten sesuai dengan perkembangan dan inovasi dalam kebidanan. Bidan dituntut untuk up to date dalam ilmu pengetahuan maupun keterampilan.

Tabel 6

Distribusi Frekuensi Informed Choice dan Informed Consent dalam Pelayanan Keluarga Berencana (KB) di Bidan Praktik Mandiri (BPM) Wilayah Bantul

\begin{tabular}{ccc}
\hline $\begin{array}{c}\text { Informed Choice dan Informed } \\
\text { Consent dalam Pelayanan KB }\end{array}$ & Frekuensi & Persentase \\
\hline Kurang & 0 & $0 \%$ \\
Cukup & 10 & $21,3 \%$ \\
Baik & 37 & $78,7 \%$ \\
\hline Jumlah & 47 & $100 \%$ \\
\hline
\end{tabular}

Sumber: Data Primer 2017

\footnotetext{
17 Pasal 1 ayat (6) Peraturan Menteri Kesehatan Nomor 161 tahun 2010 tentang Registrasi Tenaga Kesehatan

18 Pasal 1 ayat (5) Peraturan Menteri Kesehatan Nomor 161 tahun 2010 tentang Registrasi Tenaga Kesehatan

19 Pasal 2 ayat (6) Peraturan Menteri Kesehatan Nomor 161 tahun 2010 tentang Registrasi Tenaga Kesehatan

20 Pasal 9 Peraturan Menteri Kesehatan Nomor 1464 tahun 2010 tentang Izin dan Penyelenggaraan Praktik Bidan.
} 
SOEPRA Jurnal Hukum Kesehatan

TERAKREDITASI RISTEKDIKTI Peringkat 4

ISSN:2548-818X (media online) Vol. 7 (1) Juni 2021

Berdasarkan tabel 6 menunjukkan bahwa informed choice dan informed consent dalam pelayanan KB di BPM sebagian besar memiliki kategori baik sebanyak 37 BPM $(78,7 \%)$ dan tidak ada kategori kurang (0\%).

Dalam memberikan pelayanan KB, bidan tidak hanya dituntut untuk kompeten dalam ilmu pengetahuan dan keterampilan sesuai dengan perkembangan teknologi terkini, namun dalam penyelenggaraanya bidan harus menjunjung tinggi kode etik kebidanan. Kode etik bidan merupakan pedoman dalam tata cara keselarasan dalam pelaksanaan pelayanan kebidanan professional. Salah satu tujuan kode etik kebidanan untuk menjaga hak-hak pasien, salah satu hak pasien berdasarkan Peraturan Pemerintah No 61 Tahun 2014 Tentang Kesehatan Reproduksi Pasal 20 ayat 1 yang berbunyi "setiap orang berhak mendapatkan komunikasi, informasi, dan edukasi tentang keluarga berencana", hal ini menjadi landasan mendasar bagi bidan dalam pelayanan KB untuk memberikan informed choice berupa konseling menyeluruh tentang $\mathrm{KB}$, untuk mempengaruhi akseptor $\mathrm{KB}$ dalam mengambil keputusan dengan sukarela tanpa memberikan paksaan.

Setelah mendapatkan informasi menyeluruh, maka pasien bebas menentukan pilihan atau keputusan yang akan diambil. Hal ini sesuai Pasal 56 Undang-Undang No 36 Tahun 2009 Tentang Kesehatan bahwa "Setiap orang berhak menerima atau menolak sebagian atau seluruh tindakan pertolongan yang akan diberikan kepadanya setelah menerima dan memahami informasi mengenai tindakan tersebut secara lengkap". Apapun keputusan pasien setelah bidan memberikan informed choice, maka informed consent harus ditegakkan apapun keputusan pasien. Informed consent bukan sekedar formulir persetujuan yang didapat dari pasien, dan bukan sekedar tanda tangan keluarga, namun merupakan proses komunikasi. Inti dari informed consent adalah kesepakatan antara tenaga kesehatan dan klien, sedangkan formulir hanya merupakan pendokumentasian hasil kesepakatan. Persetujuan atau consent penting dari sudut pandang bidan, karena berkaitan dengan aspek hukum yang memberikan otoritas untuk semua prosedur yang akan dilakukan bidan.

Berdasarkan hasil penelitian yang dilakukan pada bidan di BPM wilayah Bantul tentang informed choice dan informed consent didapatkan hasil bahwa 37 responden $(78,7 \%)$ bidan telah mengimplementasikan informed choice dan informed consent dalam pelayanan KB di BPM dengan baik. Salah satu yang mendukung hasil implementasi informed choice dan informed consent dalam pelayanan KB di BPM Bantul baik yaitu pelatihan konseling KB, pelatihan konseling KB sangat berpengaruh terhadap pelayanan KB di BPM Wilayah Bantul. Selanjutnya untuk mengetahui implementasi informed choice dan informed consent di BPM maka penulis menggali lebih dalam dengan pertanyaan tentang pelaksanaan konseling KB, terdapat beberapa pendapat responden diantaranya responden menyampaikan pelaksanaan konseling dengan suatu media lembar balik, menjelaskan tentang prinsipprinsip dan teknik konseling dan pelaksanaan konseling menggunakan lembar balik sehingga pasien lebih paham dengan alat kontrasepsi yang akan digunakan termasuk efek samping penggunaan alat kontrasepsi. Adapun prinsip-prinsip konseling dari mulai mengucapkan salam, menggali masalah pasien/klien, melibatkan pasangan dalam konseling, menjelaskan materi konseling secara menyeluruh, mengarahkan pasien dalam pengambilan keputusan, memantapkan hasil keputusan pasien/klien, serta follow up pasien/klien setelah konseling. Berdasarkan uraian di atas menunjukkan bahwa bidan telah mengimplementasikan konseling KB dengan baik. Hal tersebut sesuai dengan Permenkes 2014 Nomor 97 tahun 2014 tentang Pelayanan Kesehatan Masa sebelum Hamil, Masa Hamil, Persalinan, dan Masa sesudah Melahirkan, Penyelenggaraan Pelayanan Kontrasepsi, serta Pelayanan Kesehatan seksual pasal 20 ayat 1 menyebutkan bahwa pemberian atau 
SOEPRA Jurnal Hukum Kesehatan

TERAKREDITASI RISTEKDIKTI Peringkat 4

ISSN:2548-818X (media online) Vol. 7 (1) Juni 2021

pemasangan kontrasepsi harus didahului oleh konseling dan persetujuan tindakan medik (Informed Consent) dalam dalam pasal 20 ayat 4 menyebutkan bahwa informasi harus diberikan secara lengkap dan cukup sehingga pasien dapat memutuskan untuk memilih metode kontrasepsi yang akan digunakan (Informed Choice).

Penulis menggali dengan pertanyaan tentang pemahaman bidan tentang tujuan konseling KB yang telah dilaksanakan di BPM serta petugas konseling KB. Jawaban responden dapat disimpulkan bahwa tujuan konseling KB yaitu pasien paham tentang seluk beluk jenis kontrasepsi yang akan digunakan dan berani mengambil keputusan jenis kontrasepsi yang akan digunakan sesuai kebutuhan dengan berdiskusi terlebih dahulu dengan pasangan. Hal ini menunjukkan bahwa bidan sudah memahami tujuan konseling. Adapun petugas konseling di semua BPM yaitu bidan, tidak ada tenaga kesehatan lain yang terlibat. Dalam buku Panduan Pelayanan Kontrasepsi disebutkan bahwa konseling KB di klinik dapat dilakukan oleh petugas medis atau paramedik terlatih di klinik yaitu, dokter, bidan, perawat serta bidan di desa ${ }^{21}$. Bidan praktik mandiri adalah praktik bidan swasta perorangan, dimana seorang bidan dapat menjalankan praktik mandiri dengan persyaratan minimal Diploma III (DIII) kebidanan dan memiliki Surat izin Praktik Bidan. ${ }^{22}$ Adapun di BPM Wilayah Bantul pelaksanaan konseling dilakukan oleh bidan atau asisten bidan dikarenakan di BPM tidak mempunyai petugas kesehatan lainnya selain bidan.

Penulis menggali informasi tentang waktu konseling KB yang bidan lakukan dan alat yang digunakan pada saat pemberian konseling pada pasien/klien. Berdasarkan hasil isian terdapat beberapa jawaban tentang waktu konseling KB, waktu konseling dilakukan pada saat sebelum menggunakan alat kontrasepsi dan setelah penggunaan bagi akseptor KB baru dan jika ada keluhan bagi akseptor lama, kapan saja saat calon akseptor KB baru datang dan pada kunjungan nifas ketiga, pada kunjungan nifas keempat, saat ada pasien Antenatal Care (ANC) serta ibu nifas yang akan ber KB. Hal ini menunjukkan bahwa sebagian besar bidan telah aktif dalam mempromosikan program KB, termasuk sejak pasien ANC. Konseling diberikan sejak ANC dengan alasan agar pasien setelah melahirkan memiliki pandangan terlebih dahulu tentang metode kontrasepsi yang akan digunakan dalam mengatur jarak kehamilan dan akan diberikan konseling kembali pada kunjungan nifas yang keempat. Kunjungan nifas keempat dalam waktu 6 minggu setelah persalinan (36-42 hari). Pada kunjungan nifas keempat bidan lebih menekankan pada motivasi KB pasca persalinan. Salah satu tujuan kunjungan nifas keempat yaitu pemberian konseling KB. Namun menurut peraturan yang baru yaitu Permenkes nomor 97 Tahun 2014 tentang Pelayanan Kesehatan Masa Sebelum Hamil, Masa Hamil, Persalinan, dan Masa Sesudah Melahirkan, Penyelenggaraan Pelayanan Kontrasepsi serta Pelayanan Kesehatan Seksual dalam pasal 15, menyebutkan bahwa kunjungan nifas paling sedikit 3 kali dan salah satu kegiatan pada kunjungan nifas ketiga yaitu pelayanan kontrasepsi pascapersalinan.

Adapun alat konseling yang digunakan sebagai pendukung konseling $\mathrm{KB}$, berdasarkan hasil penelitian semua bidan menggunakan alat pendukung konseling, yaitu menggunakan Alat Bantu Pengambilan Keputusan (ABPK) dan sebagian adanya tambahan alat peraga kontrasepsi yang berisi contoh-contoh alat kontrasepsi. Dalam buku Panduan Pelayanan Kontrasepsi dijelaskan bahwa ABPK merupakan lembar balik yang dikembangkan WHO dan telah diadaptasi untuk Indonesia oleh Starh untuk digunakan dalam konseling. ABPK

\footnotetext{
${ }^{21}$ Saifuddin, A.B, dkk, 2012, Buku Panduan Pelayanan Kontrasepsi, PT Bina Pustaka Sarwono Prawirohardjo, Jakarta.

${ }^{22}$ Pasal 3 ayat (2) Peraturan Menteri Kesehatan Nomor 1464 tahun 2010 tentang Izin dan Penyelenggaraan Praktik Bidan
} 
SOEPRA Jurnal Hukum Kesehatan

TERAKREDITASI RISTEKDIKTI Peringkat 4

ISSN:2548-818X (media online) Vol. 7 (1) Juni 2021

membantu petugas untuk memberikan konseling sesuai dengan standar. ABPK sekaligus mengajak klien bersikap lebih partisipatif dalam membantu klien mengambil keputusan ${ }^{23}$. Pada pasien baru, penggunaan contoh alat kontrasepsi sangat membantu untuk menjelaskan dan mengetahui pemahaman alat kontrasepsi. Selain itu, responden juga menggunakan media leaflet dalam membantu konseling KB. Hal ini sesuai dengan penelitian Iswarati yang menunjukkan bahwa komunikasi informasi dan edukasi (KIE) KB melalui poster/leaflet maupun televisi memperlihatkan pengaruh yang bermakna terhadap kepesertaan berKB. ${ }^{24}$

Setelah pemberian konseling, maka bidan memberikan umpan balik konseling. Umpan balik konseling sebagai sarana evaluasi apakah pasien/klien memahami yang telah bidan sampaikan. Cara memberikan umpan balik setiap bidan berbeda, ada yang hanya dengan mengetahui pasien/klien bisa memutuskan berKB sudah menjadi tolak ukur keberhasilan konseling. Adapula yang dengan memberikan pertanyaan ulang, apabila pasien/klien bisa menjelaskan kembali informasi yang telah disampaikan, maka dianggap proses konseling berhasil. Namun adapula bidan yang menyampaikan bahwa proses konseling mudah dipahami oleh pasien/klien tetapi terdapat hambatan yaitu apabila pasien/klien lebih percaya mitos atau norma masyarakat bahwa metode kontrasepsi tertentu itu dilarang/membahayakan. Peran bidan dalam keberhasilan konseling sangat penting. Selain itu, keberhasilan konseling juga dipengaruhi oleh beberapa faktor diantaranya Faktor individual dan orientasi kultural (keterikatan budaya) merupakan faktor individual yang dibawa seseorang dalam melakukan interaksi. Orientasi ini merupakan gabungan dari 1) Faktor fisik yang merupakan kepekaan panca indera yang diberi konseling akan sangat memepengaruhi kemampuan dalam menangkap informasi yang disampaikan konselor. 2) Sudut pandang yaitu nilai-nilai yang diyakini oleh pasien sebagai hasil olah pikirannya terhadap budaya dan pendidikan akan mempengaruhi pemahamannya tentang materi yang dikonselingkan. 3) Kondisi sosial yaitu status sosial dan keadaan di sekitar pasien akan memberikan pengaruh dalam memahami materi. 4) Bahasa yaitu kesamaan bahasa yang dikonselingkan dalam proses konseling akan mempengaruhi pemahaman pasien. ${ }^{25}$

Sementara itu, tujuan akhir dari proses konseling yaitu pengambilan keputusan. Bidan berperan dalam mempengaruhi pengambilan keputusan, namun tidak memberikan paksaan kepada pasien/klien. Berdasarkan hasil penelitian, didapatkan kesimpulan bahwa hak asasi pasien/klien diberikan setelah konseling, kemudian bidan membantu mengambil keputusan, namun pengambilan keputusan akhir berada di tangan pasien/klien dengan keputusan bersama pasangan. Pemberian hak dalam pengambilan keputusan diberikan sepenuhnya kepada pasien untuk memilih alat kontrasepsi sesuai pilihannya. Pilihan metode kontrasepsi yang dilakukan oleh pasangan suami istri harus mempertimbangkan usia, paritas, jumlah anak, kondisi kesehatan dan norma agama. ${ }^{26}$

Hak reproduksi perempuan merupakan bagian dari hak asasi perempuan yang dijamin pemenuhannya didalam kontitusi Negara Indonesia, sebagaimana diatur dalam pasal $28 \mathrm{H}$ ayat 1 Undang-Undang Dasar 1945, yang ditegaskan kembali dalam pasal 49 ayat 3 Undang-

\footnotetext{
23 Saifuddin, A.B, dkk, Op.Cit

24 Iswarati, 2009, Pengaruh Komunikasi, Informasi, Edukasi (KIE) KB terhadap Pelayanan KB di Indonesia, Puslitbang KB dan Kesehatan Reproduksi

25 Suyono. 2004. Tim Pelaksana Bimbingan konseling (TPBK). UNPAD. Bandung

26 Pasal 22 ayat (1) Permenkes Nomor 97 Tahun 2014 tentang Pelayanan Kesehatan Masa Sebelum Hamil, Masa Hamil, Persalinan, dan Masa Sesudah Melahirkan, Penyelenggaraan Pelayanan Kontrasepsi serta Pelayanan Kesehatan Seksual.
} 
SOEPRA Jurnal Hukum Kesehatan

TERAKREDITASI RISTEKDIKTI Peringkat 4

ISSN:2548-818X (media online) Vol. 7 (1) Juni 2021

Undang Nomor 39 tahun 1999 tentang hak asasi manusia yang berbunyi "hak khusus yang melekat pada diri wanita dikarenakan fungsi reproduksinya, dijamin dan dilindungi hukum. Hak reproduksi didalamnya menyangkut pula hak untuk mendapatkan informasi dan sarana untuk mewujudkannya, hak untuk memperoleh standar kesehatan seksual dan dan reproduksi tertinggi, dan hak untuk mengambil keputusan tentang reproduksi tanpa diskriminasi, tanpa tekanan, dan kekerasan. Hak reproduksi terkait informasi tertuang dalam pasal 72d Undang-Undang Nomor 36 tahun 2009 yaitu "memperoleh informasi, edukasi dan konseling mengenai kesehatan reproduksi yang benar dan dapat dipertanggungjawabkan". Sebelum pengambilan keputusan, maka hak pasien adalah mendapatkan informasi untuk mengambil keputusan dan mendapatkan informasi untuk memantapkan pengambilan keputusan. Berdasarkan hasil isian kuesioner bidan sepakat menyampaikan semua jenis metode kontrasepsi disampaikan sesaui kebutuhan meliputi, efektifitas, indikasi, kontra indikasi, manfaat, efek samping, dan kapan waktu penggunaan atau pemasangan bagi metode kontrasepsi yang harus dipasang. Adapun informasi yang diberikan untuk memantapkan pengambilan keputusan berdasarkan hasil penelitian yang penulis simpulkan bahwa bidan memberikan informasi yang lebih rinci sesuai dengan kebutuhan klien, memastikan pilihan alat kontrasepsi sesuai dengan kondisi kesehatan, membantu pasien memilih alat kontrasepsi lain jika yang dipilih tidak sesuai dengan kebutuhannya, merujuk pasien seandainya kontrasepsi yang dipilihnya tidak tersedia, dan memberikan konseling kunjungan ulang.

Kemantapan mengambil keputusan ini dipengaruhi oleh cara kerja masing-masing alat kontrasepsi. Hal ini menjadi penting untuk dijelaskan kepada pasien/klien agar pasien/klien memahami apabila mengalami perubahan perubahan yang terjadi dalam dirinya sebagai akibat dari cara kerja alat kontrasepsi. Hal ini akan mempengaruhi kepuasan pasien dalam menggunakan alat kontrasepsi yang nanti menjadi pengalaman yang akan diingat dalam penggunaan KB. Bidan sebagai penyedia pelayanan $\mathrm{KB}$, harus menjelaskan cara kerja alat kontrasepsi. Berdasarkan hasil penelitian, semua bidan telah menjelaskan cara kerja masingmasing alat kontrasepsi.

Informed choice merupakan suatu kondisi pasien KB yang memilih kontrasepsi didasari oleh pengetahuan yang cukup setelah mendapat informasi yang lengkap melalui konseling. Pemberian informasi dari bidan yang diperoleh pasien/klien tentang pengetahuan metode kontrasepsi secara menyeluruh dan informasi yang memantapkan pasien mengambil keputusan seperti yang telah diuraikan di atas, sesuai dengan Permenkes Nomor 97 Tahun 2014 pasal 20 ayat (1) "pemberian atau pemasangan kontrasepsi sebagaimana dimaksud dalam pasal 18 ayat (2) huruf b (tentang pemberian dan pemasangan kontrasepsi) harus didahului oleh konseling dan persetujuan tindakan medik (Informed Consent), (2) konseling sebagaimana dimaksud pada ayat (1) dapat dilakukan di fasilitas pelayanan kesehatan atau tempat pelayanan lain, (3) konseling sebagaimana dimaksud pada ayat 1 berupa komunikasi, informasi, dan edukasi tentang metode kontrasepsi, (4) yaitu informasi sebagai mana dimaksud pada ayat (3) harus dilaksanakan secara lengkap dan cukup sehingga pasien dapat memutuskan untuk memilih metode kontrasepsi yang akan digunakan (informed choice) ${ }^{27}$.

\footnotetext{
27Permenkes Nomor 97 Tahun 2014 tentang Pelayanan Kesehatan Masa Sebelum Hamil, Masa Hamil, Persalinan, dan Masa Sesudah Melahirkan, Penyelrnggaraan Pelayanan Kontrasepsi serta Pelayanan Kesehatan Seksual.
} 
SOEPRA Jurnal Hukum Kesehatan

TERAKREDITASI RISTEKDIKTI Peringkat 4

ISSN:2548-818X (media online) Vol. 7 (1) Juni 2021

Dalam menyampaikan informasi secara detail tentang berbagai jenis metode kontrasepsi, tentu ada hambatan. Berdasarkan hasil penelitian, hambatan dalam konseling antara lain, calon akseptor KB khawatir terhadap efek samping, pasien/klien kurang kooperatif dan lebih percaya adanya mitos yang telah beredar di masyarakat. Masyarakat masih menganggap bahwa penggunaan alat kontrasepsi sarat dengan efek samping dan stigmastigma yang kurang tepat. Padahal seiring dengan berkembangnya penelitian di bidang kesehatan, penggunaan metode KB memiliki potensi yang besar untuk pengobatan pada wanita seperti gangguan haid atau jerawat.

Namun, masih banyak masyarakat yang belum mendapat informasi yang tepat mengenai manfaat KB sehingga banyak tersebar mitos yang perlu diluruskan. mulai dari Pil KB yang membuat kulit wajah berjerawat, KB suntik yang membuat flek di wajah, sampai kondom yang tidak terlalu efektif mencegah kehamilan. Sesuai pernyataan responden bahwa salah satu hambatan dalam konseling KB yaitu adanya anggapan akseptor KB bahwa KB membuat badan gemuk, hal tersebut merupakan merupakan mitos. Faktanya Tidak benar, karena kandungan hormon yang ada pada setiap butir Pil KB berdosis rendah sehingga tidak akan membuat berat badan naik. Pil KB merupakan kontrasepsi oral hormonal yang diminum secara rutin setiap hari untuk mencegah kehamilan. Hormon yang terkandung di dalam Pil KB, yaitu hormon estrogen dan progesteron, adalah hormon yang sama yang diproduksi oleh tubuh wanita. Meminum Pil KB secara teratur akan membantu menstabilkan level kedua hormon di dalam tubuh. Dan hal ini yang membantu dalam pencegahan kehamilan. Kurangnya pemahaman pasien tentang konseling yang diberikan oleh bidan juga menjadi hambatan dalam pelaksanaan konseling. Hal ini sesuai dengan hasil penelitian Iswarati bahwa kurangnya informasi menyebabkan kurangnya pengetahuan klien dalam memilih jenis $\mathrm{KB}$, sedangkan pemberian $\mathrm{KIE}$ dari semua petugas berpengaruh terhadap pengambilan keputusan bersama (suami istri) untuk ber $\mathrm{KB}^{28}$. Hambatan dalam konseling yang teratasi maupun tidak teratasi mempengaruhi hasil akhir konseling, Sehingga, ketika beberapa bidan tersebut diberikan pertanyaan tentang ada atau tidak hubungan konseling yang dijelaskan dengan keputusan dalam menggunakan alat kontrasepsi, bidan yang menjadi responden sepakat bahwa ada hubungan konseling yang disampaikan dengan keputusan dalam menggunakan alat kontrasepsi.

Pengambilan keputusan dalam memilih metode kontrasepsi dipengaruhi 29 1) Faktor pasangan, yang dapat mempengaruhi motivasi dalam memilih metode kontrasepsi, yaitu meliputi umur, gaya hidup, frekuensi senggama, jumlah anak yang diinginkan (paritas), pengalaman dengan alat kontrasepsi yang lalu, sikap dari individu sendiri dan sikap dari pasangan (suami). 2) Faktor kesehatan, yang dapat mempengaruhi keadaan kontraindikasi absolute atau relative, yaitu meliputi status kesehatan, riwayat haid, riwayat keluarga, pemeriksaan fisik, dan pemeriksaan panggul. 3) Faktor metode kontrasepsi, yang berhubungan dengan tingkat penerimaan dan pemakaian yang berkesinambungan, yaitu meliputi efektivitas, efek samping, kerugian, komplikasi-komplikasi yang potensial dan besarnya biaya. Keikutsertaan seorang akseptor dalam keluarga berencana juga tidak terlepas dari perilaku kesehatan. Perilaku kesehatan pada dasarnya adalah respon seseorang terhadap stimulus yang berkaitan dengan sakit dan penyakit, sistem pelayanan kesehatan, makanan serta lingkungan. Keputusan kesertaan KB calon akseptor KB menjadi hasil akhir dari proses konseling. Keputusan dalam memilih metode kontrasepsi mana yang

\footnotetext{
${ }^{28}$ Iswarati, 2009, Pengaruh Komunikasi, Informasi, Edukasi (KIE) KB terhadap Pelayanan KB di Indonesia, Puslitbang KB dan Kesehatan Reproduksi

29 Hartanto, Hanafi, op.cit
} 
SOEPRA Jurnal Hukum Kesehatan

TERAKREDITASI RISTEKDIKTI Peringkat 4

ISSN:2548-818X (media online) Vol. 7 (1) Juni 2021

akan digunakan harus tidak ada paksaan. Berdasarkan hasil penelitian, bidan menyampaikan bahwa keputusan yang diambil pasien dalam menentukan metode kontrasepsi yang digunakan atas dasar sukarela tanpa paksaan. Hal ini berarti sudah sesuai dengan prinsip konseling. Selanjutnya apabila pasien/klien telah memberikan keputusan, selanjutnya bidan melakukan informed consent.

Hasil isian kuesioner dengan beberapa bidan tentang informed consent dalam pelayanan KB secara keseluruhan baik. Informed consent dilaksanakan setelah informed choice. Informed consent diberikan sebelum tindakan. Informed consent berisi bukti persetujuan pasien dan keluarga (suami) secara tertulis yang ditanda tangani pasien, keluarga (suami) dan bidan. Sekarang dengan semakin meningkatnya kesadaran wanita sebagai konsumen, juga berkewajiban mengambil tanggungjawab atas hasil pilihan asuhan mereka sendiri, mereka perlu diikutsertakan dalam mengambil keputusan untuk asuhan yang dialaminya ${ }^{30}$. Keterlibatan wanita atau pasien beserta keluarga dalam pengambilan keputusan sesuai dengan Permenkes Nomor 290/MenKes/Per/III/200831 dan Undang Undang Nomor 29 Tahun 2004 Pasal $45^{32}$ serta manual persetujuan tindakan medis yang diberikan oleh pasien atau keluarga terdekatnya setelah mendapatkan penjelasan secara lengkap mengenai tindakan medis yang akan dilakukan terhadap pasien.

Informed consent merupakan persetujuan yang diberikan oleh klien atau keluarganya atas dasar informasi dan penjelasan mengenai tindakan medis yang akan dilakukan terhadap klien. Informasi yang diberikan harus disampaikan selengkap-lengkapnya, jujur, dan benar tentang metode kontrasepsi yang akan digunakan klien. Setiap tindakan medis yang mengandung risiko harus dengan persetujuan tertulis yang ditandatangani oleh yang berhak memberikan persetujuan yaitu klien yang bersangkutan dalam keadaan sadar dan sehat mental. Tindakan medis seperti kontrasepsi mantap (kontap) yang berpengaruh terhadap perkawinan sehingga ijin harus dari suami istri, berbeda dengan tindakan medis lain yang tidak menyangkut organ reproduksi yang ijiinnya terutama diberikan oleh pihak yang mengalami tindakan tersebut.

Informed consent juga dianggap the right of self determination yaitu hak yang melekat dalam diri manusia, dalam arti seseorang berhak menentukan apa yang akan dilakukan atas dirinya. Hak untuk menentukan diri sendiri dalam bidang kesehatan antara lain hak untuk menentukan mendapatkan atau menolak pertolongan di bidang pelayanan kesehatan. Selain itu ditemukan juga bahwa bidan sangat menjunjung tinggi nilai-nilai etik yang dimiliki dari pelaksanaan informed consent ${ }^{33}$

Informed choice dan informed consent dalam pelayanan KB bagian dari hak kesehatan reproduksi. Hak kesehatan reproduksi adalah hak asasi manusia yang seharusnya diperoleh masyarakat khususnya akseptor KB melalui pelayanan KB berkualitas. Pelayanan berkualitas termasuk kualitas medik, artinya menawarkan kontrasepsi yang cocok dengan pelayanan yang tersedia, ditunjang dengan konseling yang tepat dan tenaga penyelenggaranya (provider) berkompeten secara teknis. Pelayanan juga harus mengakomodasi harapan perempuan yang membutuhkan hubungan interpersonal agar dapat diketahui pandangan dan pendapat perempuan ${ }^{34}$.

\footnotetext{
30 Marimbi, Hanum, 2008, Etika dan Kode Etik.Profesi kebidanan, Huha Medika, Yogyakarta.

${ }^{31}$ Permenkes Nomor 290 Tahun 2008 tentang Persetujuan Tindakan Kedokteran.

32 Pasal 45 Undang-undang Nomor 29 Tahun 2004 tentang Praktik Kedokteran

33 Marimbi, Hanum, Op.Cit

34 Prawirohardjo, sarwono, 2001, Pelayanan Kesehatan Maternal \& Neonatus, JNPKKR-POGI
} 


\section{KESIMPULAN}

1. Informed choice dan informed consent dalam pelayanan KB di BPM Wilayah Bantul kategori baik sebanyak 37 BPM (78,7\%), cukup sebanyak 10 BPM (21,3\%) dan kategori kurang tidak ada (0\%).

2. Informed choice dan informed consent dalam pelayanan KB di BPM Wilayah Bantul mayoritas baik karena didukung oleh pelatihan konseling KB dan Pelatihan Contraceptives Technology Update (CTU) yang di ikuti bidan yang memberikan pelayanan KB di BPM wilayah Bantul. Bidan yang telah melaksanakan pelatihan konseling KB sebanyak 40 orang $(85,1 \%)$ dan belum melaksanakan pelatihan konseling KB sebanyak 7 orang $(14,9 \%)$. Adapun bidan yang telah melaksanakan pelatihan CTU sebanyak 43 orang (91,5\%) dan yang belum melaksanakan pelatihan sebanyak 4 bidan (8,5\%).

3. Informed choice dan informed consent dalam pelayanan KB di BPM Wilayah Bantul pelaksanaannya sesuai dengan kewenangan dan kompetensi bidan.

\section{SARAN}

1. Bagi Profesi Bidan

a) Bidan sebaiknya mengikuti pelatihan-pelatihan yang menunjang kompetensi bidan sesuai dengan standar profesi bidan agar dapat meningkatkan mutu pelayanan dalam memberikan asuhan kebidanan. Selain itu, dalam menjalankan kewenangannya bidan harus memperhatikan informed choice dan informed consent sebelum mengambil keputusan dan melakukan tindakan medis, termasuk dalam pelayanan KB.

b) Bidan selalu meng up-date peraturan di bidang hukum kesehatan, khususnya peraturan terkait pelayanan kesehatan pada ibu dan peraturan izin dan penyelenggaraan praktik bidan.

2. Bagi Bidan Praktik Mandiri

Bidan Praktik Mandiri sebaiknya membudayakan informed choice dan informed consent dalam semua tindakan medis yang dilakukan termasuk dalam pelayanan KB. Selain itu adanya buku dokumentasi tertulis sebagai bukti pelaksanaan informed choice dan informed consent.

3. Organisasi Profesi IBI

a. Organisasi Profesi IBI sebaiknya memberikan suatu pelatihan/seminar/workshop yang berkaitan dengan pelayanan KB kepada bidan-bidan untuk meningkatkan ilmu pengetahuan dan keterampilan terkini dalam pelayanan KB.

b. Organisasi profesi sebaiknya mensosialisasikan peraturan perundang-undangan khususnya yang mengatur tentang penyelenggaraan praktek bidan.

\section{DAFTAR PUSTAKA}

, 2004, Informed Consent, Balai penerbit FKUI, Jakarta. , 2004, Medical Law, Balai Penerbit FKUI, Jakarta ,2010, Demografi dan Kependudukan Nasional, BKKBN, Jakarta , 2010, Pengantar Penelitian Hukum, UI-PRESS, Jakarta. 
, 2011, Demografi dan Kependudukan Nasional, BKKBN,Jakarta , 2012, Metode Penelitian Kuantitatif dan Kualitatif, Alfabeta, Bandung

Arikunto, Suharsimi, 2010, Prosedur Penelitian Suatu Pendekatan Praktik, PT RinekaCipta, Jakarta

Arum \& Sujiyatini, 2011, Panduan Lengkap Pelayanan KB Terkini, NuhaMedika, Yogyakarta

Baziad, Ali, 2008, Kontrasepsi Hormonal, PT Bina Pustaka Sarwono Prawirohardjo, Jakarta

BKKBN Bantul, 2015, Data Hasil Kegiatan Program KB Nasional, BKKBN, Bantul.

BKKBN DIY, 2015, Demografi dan Kependudukan Nasional, BKKBN, Yogyakarta

BKKBN, 2009, Demografi dan Kependudukan Nasional, BKKBN, Jakarta

Bulatao dan Lee. 1983, Determinant of Fertility In Developing countries, J. Po, London Academic Press

Burhan Bungin, 2007, Penelitian Kualitatif: Komunikasi, Ekonomi, Kebijakan Publik dan Ilmu Sosial Lainnya, Kencana, Jakarta.

Departemen Pendidikan Nasional, 2014, Kamus Besar Bahasa Indonesia, PT. Gramedia Pustaka Indonesia, Jakarta

Donsu, Amelia, 2012, Faktor-Faktor yang Berhubungan dengan Kinerja Bidan Desa dalam Penerapan Informed Choice dan Informed Consent Pada Pelayanan Kontrasepsi di Kabupaten Minahasa Utara, Tesis, Universitas Diponegoro Semarang

Fajrin, N, 2014, Faktor-Faktor yang Mempengaruhi Penggunaan Alat Kontrasepsi IUD Pada Pasangan Usia Subur Di Puskesmas Limba B Kecamatan Kota Selatan Kota Gorontalo, Tesis, Universitas Negeri Gorontalo

Guwandi, J, 1996, Dokter, Pasien, dan Hukum, Balai Penerbit FKUI, Jakarta

Hanafiah, Jusuf \& Amir, Amri, 2007, Etika Kedokteran dan Hukum Kesehatan, Penerbit Buku Kedokteran EGC, Jakarta

Hartanto, Hanafi, 2004, Keluarga Berencana dan Kontrasepsi, Cetakanke 5, Pustaka Harapan, Jakarta

Helmi A, 2003, Malpraktik Keperawatan, Menghindari Masalah Hukum, Penerbit Buku Kedokteran, EGC, Jakarta

Hidayat, A AA, 2014, Metode Penelitian Kebidanan dan Teknik Analisis Data, Salemba Medika, Jakarta

Icemi Sukarni K \& Wahyu P. 2013. Buku Ajar Keperawatan Maternitas, Nuha Medika Pustaka, Yogyakarta.

ICM, 1993, Kode Etik Internasional Bidan, sebagaimana dimuat dalam laman https://lenteraimpian.wordpress.com/2010/02/10/informed-choice-dan-informedconcent/terakhir diakses pada 20 Mei 2016.

Indra Bastian dan Suryono, 2011, Penyelesaian Sengketa Kesehatan, Salemba Medika, Jakarta.

Iswarati, 2009, Pengaruh Komunikasi, Informasi, Edukasi (KIE) KB terhadap Pelayanan KB di Indonesia, Puslitbang KB dan Kesehatan Reproduksi 
John W. Croswell, 2013, Research Desaign: Pendekatan Kualitatif, Kuantitatif dan Mixed, Cetakan III, PustakaPelajar, Yogyakarta.

Kamus Besar Bahasa Indonesia (KBBI) versionline/daring (dalamjaringan), sebagaimana dimuat dalam pranala http://kbbi.web.id/layan terakhir diakses 20 Mei 2016

Kementrian Kesehatan Republik Indonesia, 2012, Survei Demografi dan Kesehatan Indonesia, BKKBN, Jakarta.

Keputusan Menteri Kesehatan Nomor 369 tahun 2007 tentang Standar Profesi Bidan

Keputusan Menteri Kesehatan RI Nomor 938 tentang 2007 tentang Standar Asuhan Kebidanan

Komalawati, Veronica, 2002, Peranan Informed Consent dalam Transaksi Terapeutik (Persetujuan Dalam Hubungan Dokter dan Pasien) Suatu Tinjauan Yuridis, PT Citra Aditya Bakti, Bandung.

Konsil Kedokteran Indonesia. 2006. Penyelenggaraan Praktik Kedokteran Yang Baik di Indonesia. Jakarta.

Kusmiran, E, 2011, Kesehatan Reproduksi Remaja dan Wanita, Salemba Medika, Jakarta.

Kustriyanti, 2014, Faktor-faktor yang Berhubungan dengan Pemilihan Alat Kontrasepsi pada Wanita Usia Subur di Puskesmas Ngesrep Kelurahan Ngesrep Kecamatan Banyumanik Tahun 2014, Universitas Muhamadiyah Semarang, Tersedia dalam http://jurnal.unimus.ac.id/index.php/psn12012010/article/view/1435/1488.

Manuaba, 2008, Ilmu Kebidanan, Kandungan dan KB, Penerbit Buku Kedokteran EGC,Jakarta

Maria SW. Sumardjono, 2014, Metodologi Penelitian Ilmu Hukum, Universitas Gadjah Mada, Yogyakarta.

Marimbi, Hanum, 2008, Etika dan Kode Etik.Profesi Kebidanan, Huha Medika, Yogyakarta.

Marmi, 2014, Etika Profesi Bidan, Pustaka Pelajar, Yogyakarta

Moleong, L, 2009, Metodologi Penelitian Kualitatif Edisi Revisi, Remaja Rosdakarya, Bandung.

Muchtar, Masrudi, 2015, Bidan dan Dinamika Hukum Kesehatan Reproduksi di Indonesia, Aswaja Pressindo, Yogyakarta.

Muchtar, R \& Purnomo, E, 2009, Proximate Determinant Fertilitas di Indonesia, Puslitbang KB dan Kesehatan Reproduksi Badan Koordinasi Keluarga Berencana Nasional, BKKBN, Jakarta

Notoatmodjo, Sukidjo, 2012, Metodologi Penelitian Kesehatan, Rineka Cipta, Jakarta

Peraturan Menteri Kesehatan Nomor 1464 Tahun 2010 tentang Izin dan Penyelenggaraan Praktik Bidan (Berita Negara Republik Indonesia Tahun 2010)

Peraturan Menteri Kesehatan Nomor 97 Tahun 2014 tentang Pelayanan Kesehatan Masa Sebelum Hamil, Masa Hamil, Persalinan, dan Masa Sesudah Melahirkan, Penyelenggaraan Pelayanan Kontrasepsi serta Pelayanan Kesehatan Seksual.

Peraturan Menteri Kesehatan Republik Indonesia Nomor 290 Tahun 2008 tentang Persetujuan Tindakan Kedokteran (Berita Negara Republik Indonesia Tahun 2008)

Peraturan Pemerintah Nomor 61 Tahun 2014 Tentang Kesehatan Reproduksi 
Prawirohardjo, Sarwono, 2006, Ilmu Kebidanan, PT Bina Pustaka Sarwono Prawirohardjo, Jakarta

Proverawati, dkk, 2010, Panduan Memilih Kontrasepsi, Nuha Medika, Yogyakarta

Rianto, Adi, 2004, Metodologi Penelitian Sosial dan Hukum Edisi 1, Granit, Jakarta

Riwidikdo, Handoko, 2012, Statistik Kesehatan, Mitra Cendekia Press, Yogyakarta

Saifuddin, A.B, dkk, 2012, Buku Panduan Pelayanan Kontrasepsi, PT Bina Pustaka Sarwono Prawirohardjo, Jakarta

Sinclaire, Constance, 2009, Buku Saku Kebidanan, Penerbit Buku Kedokteran EGC, Jakarta

Singarimbun, M, 1994, Keluarga Berencana, Pusat Penelitian dan Studi Kependudukan Universitas Gadjah Mada, Yogyakarta

Soekanto, Soerjono, 2001, Penelitian Hukum Normatif Suatu Tinjauan Singkat, Radja Grafindo Persada, Jakarta

Sofwan Dahlan, 2000, Hukum Kesehatan, Rambu-Rambu bagi Profesi Dokter, Badan Penerbit Universitas Diponegoro, Semarang

Sugiono, 2010, Metodologi Penelitian dan Pendekatan Praktek, PT Rineka Cipta, Jakarta

Sulistyawati, A, 2009, Buku Ajar Asuhan Kebidanan pada Ibu Nifas, CV Andi Offset, Yogyakarta

Suyono, 2004, Tim Pelaksana Bimbingan konseling (TPBK), UNPAD, Bandung

Undang-Undang No. 29 Tahun 2004 Tentang Praktik Kedokteran (Lembaran NegaraRepublik Indonesia Tahun 2004 Nomor 116 , Tambahan Lembaran Negara Republik Indonesia Nomor 4431)

Undang-Undang No. 36 Tahun 2009 Tentang Kesehatan (Lembaran Negara Republik Indonesia Tahun 2009 Nomor 144, Tambahan Lembaran Negara Republik Indonesia Nomor 5063)

Undang-Undang No. 44 Tahun 2009 Tentang Rumah Sakit (Lembaran Negara Republik Indonesia Tahun 2009 Nomor 153, Tambahan Lembaran Negara Republik Indonesia Tahun 2009 Nomor 5072)

Undang-Undang Nomor 39 tahun 1999 tentang Hak Asasi Manusia

Varney, 2006, Buku Ajar Asuhan Kebidanan, Penerbit Buku Kedokteran EGC, Jakarta

Wiknjosastro, 2010, Ilmu Kebidanan, Yayasan Bina Pustaka, Jakarta

Yuhedi, LF \& Kurniawati, T, 2011, Buku Ajar Kependudukan dan Pelayanan KB, Penerbit Buku Kedokteran EGC, Jakarta 